\title{
Accessibility of Alabama government Web sites
}

\author{
Andrew Potter*,1 \\ 5714 Jones Valley Drive, Huntsville, AL 35802, USA
}

Received 3 May 2003; received in revised form 2 June 2003; accepted 23 June 2003

\begin{abstract}
As the World Wide Web has assumed an increasingly important role in providing government information and services, the need to extend these resources to the portion of the population with disabilities has become readily apparent. In 1998, Congress amended Section 508 of the Rehabilitation Act of 1973 to require federal government agencies and departments to ensure that their Web sites (as well as other electronic and information technology) are accessible and usable by federal employees with disabilities. Although Section 508 applies explicitly only to federal government Web sites, there are implications for the states and private sector as well. Accessible e-government means that governmental forums and services otherwise beyond the reach of disabled individuals are now easily within their grasp. This paper presents the results of an evaluation of the level of accessibility of selected state of Alabama government Web sites. While the results of this study indicate considerable improvement over earlier research, the level of accessibility remains low. The pressure to comply with accessibility standards can only be expected to increase in the future, but legislation on the state level may prove unnecessary. The adoption of standards at the federal level is generating significant momentum for both the public and private sectors. While accessibility may never reach $100 \%$, the potential for improvement remains significant.
\end{abstract}

(C) 2003 Elsevier Inc. All rights reserved.

Keywords: Web site accessibility; Section 508; Assistive Technology; Web site design

* Tel.: +1-256-881-1238.

E-mail address: apotter@hiwaay.net (A. Potter).

1352-0237/02/\$ - see front matter (C) 2003 Elsevier Inc. All rights reserved. 


\section{Introduction}

As the World Wide Web has assumed an increasingly important role in providing government information and services, the need to extend these resources to the portion of the population with disabilities has become readily apparent. The government of Alabama provides thousands of Web pages ranging from children's history lessons to daily ozone forecasts, from chiropractic license examination dates to tour schedules for the First White House of the Confederacy. Among the potential users of these resources are many disabled individuals. Nationally, over 32 million working-age people have a disability and in Alabama, over $9 \%$ of the population have a work disability (Stoddard, Jans, Ripple, \& Kraus, 1998). Because the population of the United States is aging, the proportion of disabled can be expected to increase over the next 20 years (U.S. Administration on Aging, 2001). Until recently, however, little attention has been given to ensuring that the Web is accessible to disabled persons (U.S. Department of Justice, 2000).

In 1998, Congress amended Section 508 of the Rehabilitation Act (1973) to require U.S. federal government agencies and departments to ensure that their Web sites (as well as other electronic and information technology) are accessible and usable by federal employees with disabilities (29 U.S.C. $\S 794$ d). Section 508 requires that access provided to the disabled be comparable to that provided to the public without disabilities. This law took effect on June 25, 2001 (U.S. Access Board, 2001).

Although Section 508 applies explicitly only to federal government Web sites, there are implications for the states as well. According to the U.S. Department of Education, states receiving funding under the Assistive Technology Act (29 U.S.C. $\S 3001$ et seq.) must comply with Section 508 (Heumann \& Seelman, 2000). While the department has yet to issue guidelines for compliance with this decision, its position with respect to this requirement still stands, according to Carol Cohen, with the U.S. Department of Education's Office of Special Education and Rehabilitative Services (personal communication, September 30, 2002). In the meantime, some states have enacted their own laws modeled on the federal legislation (Brewer, 2002); however, Alabama is not among these states.

This paper presents the results of an evaluation of the level of accessibility of selected Alabama government Web sites. The focus is on sites providing information services to individual citizens, such as jobs and career development, hunting and fishing, licenses and permits, and recreation and travel. The study measured the extent to which these sites were accessible to persons with disabilities, as defined by established Web accessibility standards. Where appropriate, this study makes recommendations for improved site accessibility.

\section{Literature review}

Web accessibility has been the focus of numerous studies and articles in the last few years. While the literature is almost entirely in support of increased accessibility, actual practice has been less encouraging. Studies of government, education, and private sector Web sites have uniformly found low levels of accessibility. Romano (2002) evaluated the 
Web sites of Fortune 100 companies and found that over $70 \%$ had accessibility problems, many of them severe. Báthory-Kitsz (1999) conducted a study of the Web sites of U.S. presidential candidates in the year 2000 elections and found that none of them met basic requirements for accessibility. In their study of community college Web sites, Flowers, Bray, and Algozzine (2001) found that only $23 \%$ of the sites evaluated were accessible to individuals with disabilities. Flowers, Bray, and Algozzine (1999) also studied special education home pages and found that $73 \%$ of these had accessibility problems, and that $71 \%$ of the errors were severe. In her study of federal Web sites, Stowers (2002) found that only $13.5 \%$ of the sites evaluated met the basic standards for accessibility, despite the fact that the study was performed well past the Section 508 implementation deadline.

In his series of studies of state and federal government Web sites, West found that in 2000, only in $15 \%$ of the sites surveyed provided disability access, and in Alabama, only $3 \%$ were accessible (West, 2000). By 2001, West found that the national average had risen to 27\%, and Alabama government sites had a $6 \%$ rate of accessibility (West, 2001). In his most recent study, West (2002) reported little increase nationally over the previous year (28\%), and a slight decrease in Alabama to $5 \%$, though the criteria used for accessibility were generous. More encouragingly, Schmetzke (2001a) evaluated the Web accessibility of university libraries and library schools of 24 highly ranked schools of library and information science and found that $59 \%$ of the library sites and $23 \%$ of the school sites attained approval status. Schmetzke (2001b) also evaluated accessibility of distance education Web pages and found only about $15 \%$ to be free of accessibility errors.

In her study of Web accessibility for the visually impaired at National Council for Accreditation of Teacher Education (NCATE) accredited colleges and universities in the Pacific region, Stein (2002) found an $81 \%$ failure rate for Section 508 compliance. In a similar study of NCATE accredited colleges and universities in the Mountain Region, Chilson (2002) found an $88 \%$ failure rate. Here, as in most studies, the predominant error was the omission of text equivalents for nontext elements.

\section{Technical and administrative challenges}

The reasons for low accessibility level may be both technical and administrative. Technically, the means for achieving accessibility is not obvious to Web administrators and developers who are inexperienced in this area. Indeed, prior to the widespread introduction of graphical user interfaces, there was little need for awareness of accessibility concerns among software developers. In earlier character-based user interfaces, screen reader technologies provided a sufficient level of accessibility for many disabled individuals. This is no longer the case with graphical user interfaces, because the screen reader technology is not capable of interpreting graphical content (Barnicle, 2000). In character-based systems, screen reader technology resolved many accessibility problems without requiring intervention or even awareness of software developers or system administrators. Ensuring that graphical applications and Web sites are accessible requires that developers adopt specific practices to avoid problems. 
The adoption of accessibility standards has been slow in getting started (Mayfield, 2002a). The response among government agencies has been characterized as one of regulatory confusion, inaction, and uncertainty (Britt \& Orr, 2001; Emery, 2002). The original deadline for federal agencies to comply with Section 508 passed with few federal Web sites meeting requirements (Benner, 2001). Although considerable anxiety was expressed regarding the inevitability of litigation, it seems that by focusing on remediation rather than monetary damages, Section 508 makes litigation a solution of last resort (Matthews, 2002).

In the meantime, the possibility of using the 1990 Americans with Disabilities Act to require Web accessibility was raised when the National Federation of the Blind filed suit against America Online (AOL), charging that AOL's client software violated the Act (Cisneros, 2000; Sager, 2000). AOL's software made liberal use of graphic images that were not accessible by screen reader text-to-voice technologies used by visually disabled individuals. Since the Disabilities Act applies to the private sector as well to government, the implications of the case could have had broad implications. However, the suit was settled when AOL agreed to improve accessibility in the next release of its Internet client software (Cisneros, 2000; Sager, 2000). This left unresolved the question of whether the Disabilities Act could be applied to cyberspace.

The issue resurfaced when Robert Gumson, a blind Internet user, filed suit against Southwest Airlines under the 1990 Disabilities Act because of problems in using Southwest's reservation software with screen reader technology (Mayfield, 2002b). Last October, the case was dismissed when U.S. District Judge Patricia Seitz of the Southern District of Florida ruled that the Disabilities Act was not applicable to cyberspace (Access Now, Inc. v. Southwest Airlines, Co., No. 02-21734 (S.D. FL 10/18/02)).

There are significant uncertainties associated with Web accessibility: whether there is a legislative mandate, and if so, to whom it applies and whether it would survive legal muster. The combination of these uncertainties with evolving technology can easily account for the low levels of accessibility found in the above studies. The temptation, particularly those on the periphery of controversy, such as state governments, could easily be to adopt a wait-andsee attitude.

\section{Background on alabama state government web accessibility}

Alabama state government has no comprehensive plan for addressing Web site accessibility. According to Faye Boyd, manager of Alabama.gov Internet services, each agency is responsible for setting its own policies (F. Boyd, personal communication, December 12, 2002). As part of this study, the investigator notified administrators of the sites selected for the study that their Web sites were being evaluated, and inquired whether there were ongoing projects or plans for accessibility enhancements. Some site administrators indicated that work is underway to make their sites accessible, while others indicated they were unaware of any plans in that regard. Sites whose administrators indicated that work is underway to make their sites accessible include the Alabama Department of Industrial Relations (L. Segrest, personal communication, December 12. 2002), the Alabama Emergency Management 
Agency (N. Schofield, personal communication, December 17, 2002), and the Alabama Department of Environmental Management (S. Little, personal communication, January 8, 2003). Administrators who indicated they had no plans include the Alabama National Guard (M. Dyson, personal communication, December 12, 2002), Alabama Medicaid (M. Murphy, personal communication, December 12, 2002), and the Department of Public Safety (C. Terling, personal communication, December 16, 2002). Plans for making the Alabama Legislature's Web sites more accessible were under consideration (J. Morgan, personal communication, December 16, 2002). As discussed below, several other state organizations have already adopted accessibility standards, but for the vast majority, their plans and intentions remain unknown.

\section{Project design and implementation}

While this investigation sheds some light on the future, it serves as a baseline for the current level of accessibility of Alabama state Web sites. By doing so in a manner that is consistent with previous accessibility studies, and by using the same standards and measurement tools, this investigation can add to the body of literature on the subject and provide a baseline for evaluation in subsequent studies.

\subsection{Web site selection}

The sites studied encompass a broad range of state government services and organizations. These include the "Alabama.gov" portal and all state sites providing citizen services, as designated by the portal. As Alabama's official Web site, Alabama.gov provides links to federal, state, and local government sites; civic and community organizations; and public educational institutions. The citizen's services page of Alabama.gov provides access to a wide range of topics of interest to individual users, such as elections and voting, jobs and career development, hunting and fishing, licenses and permits, and recreation and travel. The complete list of Web sites evaluated may be found in the Appendix.

\subsection{Accessibility evaluation tool}

The author used Watchfire Bobby 4.0.1 to collect Web site accessibility data. Widely used in accessibility studies, Bobby is a testing tool that identifies and prioritizes Web site accessibility problems (Watchfire, 2002). Significant studies employing Bobby include Chilson (2002), Flowers et al. (1999; 2001), Graves (2001), Romano (2002), Stein (2002), Stowers (2002), and West $(2000 ; 2001 ; 2002)$. Such wide level of acceptance provides a basis for comparing the results of the current study with previous research.

Bobby is available in three versions: an online service, a single user desktop version, and a server version. The online version is available for free, whereas the desktop version and server versions must be purchased (US\$99.00 and US\$3000.00, respectively). The online version is useful for evaluating individual Web pages, the desktop version is suitable for 
testing entire sites, and the server version enables multiple testers within an organization to assess a single installation. It has not always been clear in previous studies which version the authors used, but the evaluation criteria appear to be consistent. The version of Bobby used in this study is the desktop version.

Bobby evaluations are based on two accessibility standards: the World Wide Web Consortium's Web Accessibility Initiative (WAI) and Section 508 (Watchfire, 2002). WAI checkpoints are prioritized with respect to severity, Priority 1 accessibility problems being the most significant and Priority 3 the least (World Wide Web Consortium, 1999). Priority 1 errors are considered severe enough to prevent disabled users from making effective use of the site. A common example of a Priority 1 error is failure to provide alternative text for graphic information included on a Web page. The Section 508 evaluation checks for conformance to Section 508 of the Rehabilitation Act and roughly mirrors the WAI standards, although WAI provides a more detailed analysis.

As summarized in Fig. 1, Bobby provides an approval rating that reflects the guidelines established by $\mathrm{W} 3 \mathrm{C}$. Conformance Level $A$ is granted to sites that are free of Priority 1 problems, Conformance Level $A A$ is granted to sites that are free of Priorities 1 and 2 problems, and Conformance Level $A A A$ is assigned to sites that are free of Priority 1, 2, and 3 problems. Similarly, sites that are free of Section 508 errors are qualified for the Bobby Approved 508. For each level of approval, Watchfire provides an approval logo that may be displayed on the Web site.

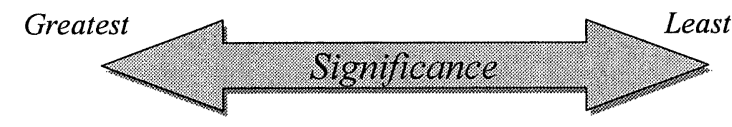

\begin{tabular}{lccc}
$\begin{array}{l}\text { W3C WAI } \\
\text { Priority }\end{array}$ & 1 & 2 & 3 \\
& $\begin{array}{c}\text { Must be } \\
\text { satisfied }\end{array}$ & $\begin{array}{c}\text { Should be } \\
\text { satisfied }\end{array}$ & $\begin{array}{c}\text { May be } \\
\text { satisfied }\end{array}$ \\
\hline Example & $\begin{array}{c}\text { Provide } \\
\text { alternative } \\
\text { text for } \\
\text { images }\end{array}$ & $\begin{array}{c}\text { Do not use } \\
\text { tables for } \\
\text { layout }\end{array}$ & $\begin{array}{c}\text { Provide } \\
\text { logical } \\
\text { sequence for } \\
\text { tab navigation }\end{array}$ \\
\cline { 2 - 4 } Conformance & A & AA & AAA \\
Level & $\begin{array}{c}\text { Priority 1 } \\
\text { satisfied }\end{array}$ & $\begin{array}{c}\text { Priorities } \\
1 \& 2\end{array}$ & $\begin{array}{c}\text { Priorities } \\
1,2 \& 3 \\
\text { satisfied } 3\end{array}$ \\
& & & satisfied
\end{tabular}

Fig. 1. Accessibility priorities and corresponding site conformance levels. 


\subsection{Procedure}

The author used the Watchfire Bobby accessibility validation tool to analyze the homepage of each selected site. For each site, data were collected for the number and priority of errors found. The data collection was performed on January 26, 2003. Bobby collects error data on each site and summarizes according to priority. Site-specific details were then obtained by double-clicking an item in the summary. This summary identifies each of the accessibility errors found and provides the line number for each error. Due to limitations in automated testing, some manual intervention was required. For example, Bobby inspects references to graphic images to ensure that text labels accompany them, but the software cannot determine whether the labels are informative. Because text labels occasionally identify only the filename for the image, it is useful to inspect labels visually.

\section{Results and outcomes}

The study evaluated each site for conformance to WAI standards and Section 508 as reflected in the Bobby automated test. The Appendix shows the number of errors of each priority for each site. Table 1 shows the number and percentage of sites achieving each approval level. As indicated, 19\% of the evaluated sites rated Conformance Level A, and 16\% achieved section 508 approval as measured by Bobby.

The site with the highest level of accessibility was Alabama.gov, which serves as a portal site to other state government sites, as well as to a variety of other information resources. Alabama.gov was the only site to achieve Conformance Level AA, and it came close to achieving Conformance Level AAA. Only one Priority 3 accessibility problem was detected, and this was omission of the language of the document, as required by WAI guidelines. This could easily be corrected by the insertion of a language attribute in the Web page HTML element:

$$
<\text { HTML lang= "en" > }
$$

Other Web sites that fared well include the Alabama Public Library Service site, Alabama Department of Human Resources, the Office of the Governor, and the Governor's Office on Disability. These sites shared little in common beyond their excellent accessibility rating.

Table 1

Web site accessibility for each Bobby conformance level

\begin{tabular}{lllll}
\hline & \multicolumn{2}{l}{ Accessibility rating } & & AAA \\
\cline { 2 - 5 } Level & A & AA & 0 & 508 \\
\hline Number & 12 & 1 & 0 & 10 \\
Percent & 19 & 2 & 0 & 16 \\
\hline
\end{tabular}


With regard to layout, style, and artwork, they appear to have been authored independently of one another.

Sites doing poorly include the Alabama Department of Revenue, the Alabama Shakespeare Festival, the Alabama Forestry Commission, and the Alabama Department of Transportation. For the most part, the errors found in these sites were typical of the study at large; they simply had more of them. The Department of Revenue site included applets, images, and image maps without alternative text; the Shakespeare Festival site used image-type buttons, images, and image maps without alternative text, and Forestry included applets, images, and image maps without alternative text.

Although the Department of Transportation scored well, the results are misleading. The site makes extensive use of scripts to provide dynamically configured menus and images, and other images are embedded in tables. Bobby was unable to analyze this site accurately. Among the Priority 1 errors clearly observable were numerous instances of failure to provide alternative text for images and alternative content for scripts.

Table 2 summarizes the Priority 1 errors found in the survey. The most frequently occurring Priority 1 error was the failure to provide alternative text for graphic images. Both WAI and 508 standards require Web pages to provide a short alternative text description for all graphic images appearing on the page. Of the 63 sites surveyed, Bobby detected 44 with this error, or $70 \%$. Moreover, Bobby was unable to identify all instances of this error. Bobby fails to detect images that occur within HTML table cells. In manually inspecting the HTML source for each page, the author found that 50 sites referenced images from within HTML tables without providing alternative text. This places the frequency of the error at close to $80 \%$.

In five sites, Web pages contained alternative text labels, but the labels were nondescriptive. For example, Peace Officers Annuity Fund site labeled an image "title2.GIF" which identifies the image file name but gives no useful indication of the information content of the image. This brings the total number of pages with this error to 54 , or $86 \%$ of the sites surveyed.

Other frequently occurring errors were of a similar nature. Nine used image map hot spots without providing alternative text, six neglected to provide alternative text for applets, and one failed to provide alternative text for images used as buttons in forms. The other Priority 1 error occurring in the sites surveyed was the failure to name frames. This omission can render multiframe pages incomprehensible when accessed using voice-to-text technology.

Table 2

Total sites for each Priority 1 error type

\begin{tabular}{lc}
\hline Priority 1 error types & Sites \\
\hline Provide alternative text for all images & 55 \\
Give each frame a title & 4 \\
Provide alternative text for each applet & 6 \\
Provide alternative text for all image map hot-spots & 9 \\
Provide alternative text for all image-type buttons in forms & 1 \\
\hline
\end{tabular}


The correspondence between Priority 1 WAI errors and Section 508 errors was high. On only two sites did Bobby detect a Section 508 error without detecting a WAI error. In both of these cases, the error was a failure to label a form control. The WAI specifies an identical standard, but it is defined as a Priority 2 rather than a Priority 1 requirement. Although some sites, such as the Alabama.gov portal, had links to text equivalent pages, these pages were not available at the time of the survey. This may have been due to an ongoing transition in state administration.

Sixteen percent of the sites surveyed met Section 508 accessibility standards as measured by Bobby. Nineteen percent of the sites reached Level A approval level, indicating they were free of detectable WAI Priority 1 errors, and only one site, the Alabama.gov portal, achieved AA approval indicating it was free of both Priorities 1 and 2 errors. None of the sites surveyed achieved WAI AAA status.

While these rates are low, they compare favorably with West's (2002) most recent accessibility data for Alabama government sites, which indicated only 5\% of Alabama sites met minimal standards. The data used in the West study were gathered during the summer of 2002; the data used in the present study were gathered in January 2003. Since specific site data are not provided in West's study, a definitive comparison cannot be made.

More importantly, the most common accessibility errors can be easily fixed. As noted earlier, the most common error was the lack of text descriptions for graphic images. In many sites, these were the only severe errors. For the sites studied, correcting these errors alone would boost the WAI Conformance Level A rate to $77 \%$ and the Section 508 rate to $63 \%$. Under WAI Guidelines, only Level A is regarded as mandatory (World Wide Web Consortium, 1999). In other words, with only minor changes, dramatic improvements could be realized.

\section{Outlook for accessibility}

The pressure to comply with accessibility standards can only be expected to increase in the future. Legislation on the state level may prove unnecessary. The adoption of standards at the federal level is generating significant momentum in both the public and private sectors. The sheer size of the federal government makes it a strong influence in all areas of information technology. Federal spending on e-government is expected to increase from US\$2.9 billion dollars in 2002 to over US\$5 billion in 2007 (INPUT, 2002a), and overall federal IT spending is projected to reach US\$63 billion dollars in 2007 (INPUT, 2002b). In making these expenditures, agencies and departments are required to give priority to products that are Section 508 compliant (Information Technology Technical Assistance and Training Center, 2001). Consequently, the adoption of accessibility standards by the federal government tends to introduce new efficiencies for state, commercial, and private sectors. Some dominant software and media vendors, including Microsoft, IBM, Apple, Adobe, and RealNetworks have already responded by pledging support for Section 508 accessibility standards (ComputerWire, 2002).

Although early cost estimates for Section 508 compliance were high, they may have been excessive. Initial estimates set the cost to the federal government as high as US\$691 million 
annually (Dorobek, 2000), and subsequently these estimates rose to US\$1.1 billion annually (Matthews, 2001). However, the actual costs are suspect and largely impossible to determine because organizational spending on accessibility has been aggregated with overall technology spending (Emery, 2002; Matthews, 2000). In any case, as shown here, small changes can make vast improvements in Web site accessibility.

It has been contended that accessibility standards should be opposed because they are an affront to freedom of expression (Olson, 2000). In this view, mandating accessibility standards is tantamount to dictating aesthetic standards to artists. While a full discussion of the greater role of standards in aesthetics is beyond the scope of this paper, the evidence suggests that it is possible to design highly effective and compelling Web sites without compromising on accessibility.

Slatin (2001) advanced the concept of Access-first design, which is based on the principle that any site that is aesthetically rich and meaningful for the disabled is likely to be rich and meaningful for others as well. Similarly, Weeks (1997) provides specific accessibility guidelines that would confirm Slatin's concept of Access-first design. Following the same general line of argument, Boldyreff, Burd, Donkin, \& Marshall (2001) argue that by enhancing the usability of text-to-voice technology through the use of plain English, designers will ultimately create Web pages that are more comprehensible to the general user. Indeed, the design constraints imposed by accessibility standards may be as likely to inspire creativity as they are to diminish it. As Taub (1999) has observed, many inventions initially developed for the disabled have found their way into mainstream use, including the phonograph, the typewriter, close-captioned television, and optical character recognition software. As a more recent example, the Segway Human Transporter was inspired by an earlier invention intended as an all-terrain replacement for the wheelchair (Delio, 2001). In the long run, accessibility standards may be seen as a driving force behind software innovation.

Organizations requiring assistance in making their Web sites accessible will find a wide arrange of available resources. A variety of tools is available, including Watchfire Bobby, the Web Design Group's HTML Validator, A-Prompt's Web Accessibility Verifier, WAVE from Pennsylvania's Initiative on Assistive Technology, and Deque Systems' RAMP product suite (Government Computer News, 2002). In addition, several products have emerged that integrate Web development with accessibility verification, such as AccVerify for Microsoft FrontPage (HiSoftware, 2002), the PageScreamer Plug-In for FrontPage 2000 (Hallogram Publishing, 2002), and Macromedia's accessibility templates for Dreamweaver (Macromedia, 2003). In addition, numerous contracting and consulting services are available to assist organizations in making their Web sites accessible (Government Computer News, 2002).

\section{Conclusions}

Because of the large and growing number of disabled individuals, and because of the increasing significance of the Web to commerce, government, education, and recreation, Web site accessibility is an area of mounting importance for information policy. In particular, e-government provides an effective means for all citizens to interact with large governmental 
bureaucracies. Accessible e-government means that governmental forums and services otherwise beyond the reach of disabled individuals are now easily within their grasp.

In previous accessibility research, Alabama government Web sites have fared poorly when compared with other states. In 2000, West found Alabama in an eight-way tie for 38th place with Delaware, Louisiana, Nevada, New Jersey, New York, North Carolina, and South Dakota. In 2001, Alabama's position relative to the other states fell to 47th, where it remained in West's (2002) most recent study. Although the findings of the present study do indicate a higher level of accessibility than reported by West, they do nothing to dispel the notion that much remains to be done before an acceptable level of accessibility is achieved.

\section{Appendix}

\begin{tabular}{|c|c|c|c|c|c|}
\hline Site & URL & $\mathrm{P} 1$ & $\mathrm{P} 2$ & P3 & 508 \\
\hline Alabama Board of Architects & http://www.alarchbd.state.al.us & 1 & 3 & 2 & 1 \\
\hline Alabama Board of Nursing & http://www.abn.state.al.us & 1 & 2 & 2 & 1 \\
\hline Alabama Crime Victims & http://www.acvcc.state.al.us & 1 & 3 & 3 & 1 \\
\hline Compensation Commission & & & & & \\
\hline Alabama Department of Agriculture & http://www.agi.state.al.us & 2 & 4 & 2 & 2 \\
\hline $\begin{array}{l}\text { Alabama Department of } \\
\text { Corrections }\end{array}$ & http://doc.state.al.us & 1 & 2 & 3 & 1 \\
\hline $\begin{array}{l}\text { Alabama Department of Forensic } \\
\text { Sciences }\end{array}$ & http://adfs.state.al.us & 1 & 4 & 3 & 1 \\
\hline $\begin{array}{l}\text { Alabama Department of Human } \\
\text { Resources }\end{array}$ & http://www.dhr.state.al.us & 0 & 2 & 1 & 0 \\
\hline $\begin{array}{l}\text { Alabama Department of Industrial } \\
\text { Relations }^{2}\end{array}$ & http://www.dir.state.al.us & 0 & 2 & 4 & 1 \\
\hline $\begin{array}{l}\text { Alabama Department of Public } \\
\text { Health }\end{array}$ & http://www.adph.org & 1 & 2 & 2 & 1 \\
\hline Alabama Department of Public Safety & http://www.dps.state.al.us & 1 & 2 & 3 & 2 \\
\hline Alabama Department of Revenue & http://www.ador.state.al.us & 3 & 3 & 4 & 3 \\
\hline $\begin{array}{l}\text { Alabama Department of Senior } \\
\text { Services }\end{array}$ & http://www.adss.state.al.us & 1 & 3 & 3 & 1 \\
\hline $\begin{array}{l}\text { Alabama Department of Veterans } \\
\text { Affairs }\end{array}$ & http://www.va.state.al.us & 1 & 2 & 2 & 1 \\
\hline Alabama Electrical Contractors Board & http://www.aecb.state.al.us & 1 & 1 & 2 & 1 \\
\hline $\begin{array}{l}\text { Alabama Emergency Management } \\
\text { Agency }\end{array}$ & http://www.aema.state.al.us & 1 & 3 & 3 & 1 \\
\hline $\begin{array}{l}\text { Alabama Home Builders Licensure } \\
\text { Board }\end{array}$ & http://hblb.state.al.us & 1 & 1 & 2 & 1 \\
\hline Alabama Homeland Security & http://homelandsecurity.alabama.gov & 1 & 3 & 3 & 2 \\
\hline Alabama Homeland Security & http://homelandsecurity.alabama.gov & 1 & 3 & 3 & 2 \\
\hline
\end{tabular}




\begin{tabular}{|c|c|c|c|c|c|}
\hline Site & URL & $\mathrm{P} 1$ & $\mathrm{P} 2$ & P3 & 508 \\
\hline Alabama Judicial System Online & http://www.judicial.state.al.us & 1 & 3 & 4 & 2 \\
\hline Alabama Law Institute & http://ali.state.al.us & 1 & 1 & 1 & 1 \\
\hline Alabama Legislative Fiscal Office & http://www.lfo.state.al.us & 1 & 3 & 2 & 1 \\
\hline Alabama Legislative & http://alisdb.legislature.state & 1 & 1 & 1 & 1 \\
\hline Information System & .al.us/acas/ACASLogin.asp & & & & \\
\hline Alabama Legislature & http://www.legislature.state.al.us & 1 & 3 & 2 & 1 \\
\hline Alabama Medicaid & http://www.medicaid.state.al.us & 1 & 3 & 2 & 1 \\
\hline Alabama National Guard & http://alguard.state.al.us & 2 & 2 & 2 & 2 \\
\hline Alabama Onsite Wastewater Board & http://aowb.state.al.us & 1 & 3 & 3 & 1 \\
\hline $\begin{array}{l}\text { Alabama Plumbers \& Gas Fitters } \\
\text { Examining Board }\end{array}$ & http://pgfb.state.al.us & 1 & 2 & 2 & 1 \\
\hline Alabama Public Library Service & http://www.apls.state.al.us & 0 & 1 & 3 & 0 \\
\hline $\begin{array}{l}\text { Alabama Public Service } \\
\text { Commission }\end{array}$ & http://www.psc.state.al.us & - & - & - & - \\
\hline Alabama Real Estate Commission & http://www.arec.state.al.us & 1 & 3 & 3 & 2 \\
\hline Alabama Shakespeare Festival & http://www.asf.net & 3 & 3 & 5 & 2 \\
\hline Alabama State Auditor's Office & http://www.auditor.state.al.us & 1 & 3 & 3 & 1 \\
\hline $\begin{array}{l}\text { Alabama State Board of } \\
\text { Auctioneers }\end{array}$ & http://www.auctioneer.state.al.us & 1 & 2 & 3 & 1 \\
\hline $\begin{array}{l}\text { Alabama State Board of } \\
\text { Public Accountancy }\end{array}$ & http://asbpa.state.al.us & 1 & 2 & 2 & 1 \\
\hline $\begin{array}{l}\text { Alabama State Board of Social } \\
\text { Work Examiners }\end{array}$ & http://abswe.state.al.us & 1 & 2 & 2 & 1 \\
\hline Alabama State Capitol Police ${ }^{3}$ & http://www.capitolpolice.state.al.us & 0 & 2 & 2 & 0 \\
\hline Alabama State Council on the Arts & http://www.arts.state.al.us & 1 & 3 & 2 & 1 \\
\hline Alabama's Aerospace Attractions & http://aerospace.state.al.us & 1 & 2 & 1 & 1 \\
\hline Alabama.gov & http://www.alabama.gov & 0 & 0 & 1 & 0 \\
\hline Attorney General & http://www.ago.state.al.us & 1 & 3 & 4 & 2 \\
\hline $\begin{array}{l}\text { Board of Heating \& Air } \\
\text { Conditioning Contractors }\end{array}$ & http://www.hvacboard.state.al.us & 1 & 1 & 2 & 1 \\
\hline Children's Trust Fund of Alabama & http://ctf.state.al.us & 1 & 4 & 3 & 1 \\
\hline $\begin{array}{l}\text { Department of Archives \& } \\
\text { History }\end{array}$ & http://www.archives.state.al.us & 1 & 2 & 4 & 2 \\
\hline Department of Children's Affairs & http://dca.state.al.us & 2 & 3 & 4 & 2 \\
\hline $\begin{array}{l}\text { Department of Conservation and } \\
\text { Natural Resources }\end{array}$ & http://www.denr.state.al.us & 3 & 3 & 3 & 3 \\
\hline $\begin{array}{l}\text { Department of Mental Health } \\
\text { and Mental Retardation }\end{array}$ & http://www.mh.state.al.us & 1 & 2 & 3 & 1 \\
\hline Department of Transportation ${ }^{4}$ & http://www.dot.state.al.us & 0 & 2 & 2 & 0 \\
\hline Economic and Community Affairs & http://www.adeca.state.al.us & 1 & 1 & 3 & 1 \\
\hline Environmental Management & http://www.adem.state.al.us & 1 & 4 & 3 & 1 \\
\hline
\end{tabular}




\begin{tabular}{|c|c|c|c|c|c|}
\hline Site & URL & P1 & $\mathrm{P} 2$ & P3 & 508 \\
\hline Forestry Commission & http://www.forestry.state.al.us & 3 & 3 & 4 & 4 \\
\hline $\begin{array}{l}\text { Garrett Coliseum } \\
\text { (Agriculture Center Board) }\end{array}$ & http://www.garrett.state.al.us & 1 & 2 & 3 & 1 \\
\hline Geological Survey of Alabama & http://www.gsa.state.al.us & 1 & 2 & 1 & 1 \\
\hline Governor's Office on Disability & http://www.good.state.al.us & 0 & 3 & 2 & 1 \\
\hline $\begin{array}{l}\text { Governor's Office On National } \\
\text { and Community Service }\end{array}$ & http://goncs.state.al.us & 2 & 2 & 3 & 2 \\
\hline Indian Affairs Commission & http://aiac.state.al.us & 1 & 3 & 3 & 1 \\
\hline Lieutenant Governor & http://www.ltgov.state.al.us & 2 & 2 & 3 & 2 \\
\hline Marriage and Family Therapy & http://www.mft.state.al.us & 1 & 2 & 2 & 1 \\
\hline Office of the Governor ${ }^{5}$ & http://www.governor.state.al.us & 0 & 1 & 1 & 0 \\
\hline Office of the Secretary of State ${ }^{6}$ & http://www.sos.state.al.us & 0 & 2 & 3 & 0 \\
\hline Peace Officers Annuity Fund ${ }^{7}$ & http://www.apoabf.state.al.us & 0 & 2 & 2 & 0 \\
\hline $\begin{array}{l}\text { Peace Officers Standards and } \\
\text { Training Commission }\end{array}$ & http://apostc.state.al.us & 0 & 2 & 2 & 0 \\
\hline $\begin{array}{l}\text { State Licensing Board for } \\
\text { General Contractors }\end{array}$ & http://www.genconbd.state.al.us & 1 & 2 & 2 & 1 \\
\hline $\begin{array}{l}\text { State of Alabama Board of } \\
\text { Physical Therapy }\end{array}$ & http://www.pt.state.al.us & 1 & 2 & 2 & 1 \\
\hline State Personnel Department & http://www.personnel.state.al.us & 0 & 2 & 2 & 0 \\
\hline
\end{tabular}

\section{Notes}

1. Andrew Potter has been involved in a wide range of software research and development projects during the past 20 years. His current work includes Web accessibility, application usability, and distributed knowledge-based systems.

2. Contains uninformative image labels, e.g. "page header" and "footer."

3. Contains uninformative image labels, e.g. "toptitle.GIF."

4. Bobby was unable to analyze portions of this site.

5. Due to a change in administration, the Governor's Web site was in a state of transition at the time of the study.

6. It appears that Bobby does not notice unlabeled images when they occur in a table cell.

7. Contains uninformative image labels, e.g. "title2.gif."

8. Contains uninformative image labels, e.g. "apostctitle2.GIF."

\section{References}

Barnicle, K. (2000). Usability testing with screen reading technology in a Windows environment. In Proceedings on the conference on universal usability, 2000 on Conference on Universal Usability (pp. 102-109). New York: ACM Press.

Báthory-Kitsz, D. (1999, December 9). Web accessibility of the presidential candidate sites. Available at: http:// orbitaccess.com/presidential/index.html. Retrieved December 31, 2002. 
Benner, J. (2001, June 25). Disabled access now, more or less. Wired News. Available at: http://www.wired.com/ news/print/0,1294,44724,00.html. Retrieved February 1, 2003.

Boldyreff, C., Burd, E., Donkin, J., \& Marshall, S. (2001). The case for the use of plain English to increase Web accessibility. Paper presented at the meeting of the Proceedings of the 3rd International Workshop on Web Site Evolution (WSE'01).

Brewer, J. (2002, October 17). United States: state policies relating to Web accessibility. http://www.w3.org/WAI/ Policy/USA-States.html. Retrieved December 15, 2002.

Britt, J., \& Orr, T. L. (2001, April 12). GSA releases final FAR rules on section 508. Government Computer News, 20 (9) (Available at: http://www.gcn.com/vol20 no9/news/4076-1.html. Retrieved January 20, 2002.

Chilson, M. E. (2002). Web site accessibility for the visually impaired and Web policy at NCATE accredited colleges and universities in the mountain region. Unpublished doctoral dissertation, Idaho State University.

Cisneros, O. S. (2000, July 28). AOL settles accessibility suit. Wired News. Available at: http://www.wired.com/ news/business/0,1367,37845,00.html. Retrieved January 31, 2003.

ComputerWire. (2002, December 20). W3C sets specs for browser, player accessibility. The Register. Available at: http://www.theregister.co.uk/content/6/28648.html. Retrieved January 1, 2003.

Delio, M. (2001, December 7). What about Kamen's other machine? Wired News. Available at: http://www. wired.com/news/gizmos/0,1452,48908,00.html. Retrieved February 9, 2003.

Dorobek, C. J. (2000, April 17). Agencies fear Sect. 508 costs. Government Computer News, 19 (8) (Available at: http://www.gcn.com/vol19_no8/news/1733-1.html. Retrieved February 2, 2003.

Emery, G. R. (2002). Section 508 'not as hard as people thought'. Washington Technology, 17 (4) (http:// www.washingtontechnology.com/news/17_4/federal/18272-5.html. Retrieved December 25, 2002.

Flowers, C., Bray, M., \& Algozzine, R. F. (2001). Content accessibility of community college Web sites. Community College Journal of Research \& Practice, 25, 475-485.

Flowers, C. P., Bray, M., \& Algozzine, R. F. (1999). Accessibility of special education program home pages. Journal of Special Education Technology, 14 (2), 21-26.

Government Computer News. (2002, December 18). Section 508 resources. Available at: http://www.gcn.com/ Resource/section508/index.html. Retrieved February 2, 2003.

Graves, S. (2001, August 13). What Bobby found this year: commerce had no errors. Government Computer News, 20 (23) (Available at: http://www.gcn.com/20_23/reviews/16783-2.html. Retrieved January 2, 2003.

Hallogram Publishing. (2002). PageScreamer plug-in for Front Page. Available at: http://www.hallogram.com/ pagescreamer/front/. Retrieved February 3, 2003.

Heumann, J., \& Seelman, K. D. (2000, April 21). NIDRR letter to states regarding Section 508, April 21, 2000. Available at: http://www.resna.org/taproject/policy/initiatives/nidrrletter.html. Retrieved December 24, 2002.

HiSoftware. (2002). Microsoft and HiSoftware have formed a strategic relationship in order to bring you AccVerify SE for FrontPage. Available at: http://www.hisoftware.com/msacc/. Retrieved February 2, 2003.

Information Technology Technical Assistance and Training Center. (2001, May 15). Section 508 overview for managers. Available at: http://www.ittatc.org/laws/508/technology.html. Retrieved January 30, 2002.

INPUT. (2002a, December 18). Federal e-government spending to exceed \$5 billion. Available at: http:// www.input.com/index_v1_about.cfm?page=include_v1_article_detail\&article_id=650. Retrieved January 1, 2003.

INPUT. (2002b, May 1). Federal IT spending to reach $\$ 63$ billion. Available at: http://www.input.com/index v1_about.cfm?page=include_v1_article_detail\&article_id=477. Retrieved January 1, 2003.

Macromedia. (2003). Accessibility: tools. Available at: http://www.macromedia.com/macromedia/accessibility/ tools/. Retrieved February 2, 2003.

Matthews, W. (2000, August 7). Access.gov. Federal Computer Week. Available at: http://www.fcw.com/fcw/ articles/2000/0807/cov-access-08-07-00.asp. Retrieved February 2, 2003.

Matthews, W. (2001, January 8). Access Board standards out. Federal Computer Week. Available at: http:// www.fcw.com/fcw/articles/2001/0108/mgt-access-01-08-01.asp. Retrieved February 2, 2003. 
Matthews, W. (2002, June 24). Remediation, not litigation. Federal Computer Week. Available at: http:// www.fcw.com/fcw/articles/2002/0624/cov-5082-06-24-02.asp. Retrieved February 2, 2003.

Mayfield, K. (2002a, June 21). Tech access law: slow progress. Wired News. Available at: http://www.wired.com/ news/technology/0,1282,53376,00.html. Retrieved February 1, 2003.

Mayfield, K. (2002b, October 14). Man sues airline for fare access. Wired News. Available at: http:// www.wired.com/news/politics/0,1283,55708,00.html. Retrieved January 31, 2003.

Olson, W. (2000, May). Access excess: the Americans with disabilities act goes online. Reason, 49-51.

Rehabilitation Act, as amended 29 U.S.C. § 794d (1973).

Romano, N. C. (2002). Customer relationship management for the Web-access challenged: inaccessibility of the Fortune 100 Web sites. Hawaii International Conference on System Sciences, 35.

Sager, R. H. (2000, November). Don't disable the Web. American Spectator, 62-63.

Schmetzke, A. (2001a). Online distance education: "anytime, anywhere" but not for everyone. Information Technology and Disabilities, 7 (2) (Available at: http://www.rit.edu/ easi/itd/itdv07n2/axel.htm. Retrieved January 30, 2003.

Schmetzke, A. (2001b). Web accessibility at university libraries and library schools. Library Hi Tech, 19 (1), $35-49$.

Slatin, J. M. (2001). The art of ALT: toward a more accessible Web. Computers and Composition, 18, $72-81$.

Stein, M. M. (2002). Web site accessibility for the visually impaired and Web policy at NCATE accredited colleges and universities in the pacific region. Unpublished doctoral dissertation, Idaho State University.

Stoddard, S., Jans, L., Ripple, J. M., \& Kraus, L. (1998). Chartbook on work and disability. Available at: http:// www.infouse.com/disabilitydata/workdisability.html. Retrieved January 4, 2003.

Stowers, G. (2002, August). The State of federal Web sites: the pursuit of excellence. Available at: http:// endowment.pwcglobal.com/pdfs/StowersReport0802.pdf. Retrieved December 20, 2002.

Taub, E. A. (1999, October 28). The blind lead the sighted. New York Times, 1.

U.S. Access Board. (2001). Standards for electronic and information technology: an overview. Available at: http:// www.access-board.gov/sec508/summary.htm. Retrieved December 1, 2002.

U.S. Administration on Aging. (2001). Profile of older Americans: 2000. Available at: http://www.aoa.gov/aoa/ stats/profile/profile2000.html. Retrieved March 1, 2003.

U.S. Department of Justice. (2000). Information technology and people with disabilities: the current state of federal accessibility. Available at: http://www.usdoj.gov/crt/508/report/content.htm. Retrieved January 4, 2003.

Watchfire. (2002). Bobby worldwide. Available at: http://bobby.watchfire.com/bobby/html/en/index.jsp. Retrieved January 2, 2003.

Weeks, C. E. (1997). How to Design an aesthetically-pleasing, ADA-compliant Web site. Paper presented at the meeting of the Proceedings of the 25th annual ACM SIGUCCS conference on User services, Monterey, CA, United States.

West, D. M. (2000, September). Assessing e-government: the Internet, democracy, and service delivery by state and federal governments. Available at: http://www.brown.edu/Departments/Taubman_Center/polreports/ egovtreport00.html. Retrieved December 1, 2002.

West, D. M. (2001, September). State and federal e-government in the United States, 2001. Available at: http:// www.brown.edu/Departments/Taubman_Center/polreports/egovt01us.html. Retrieved January 29, 2003.

West, D. M. (2002, September). State and federal e-government in the United States, 2002. Available at: http:// www.insidepolitics.org/egovt02us.PDF. Retrieved September 30, 2002.

World Wide Web Consortium. (1999). Web content accessibility guidelines 1.0. Available at: http://www.w3.org/ TR/WAI-WEBCONTENT/. Retrieved January 31, 2003. 